\title{
Kırsal Turizm ve Vernaküler Mobilya Etkileşiminde Deformasyon Kavramı
}

\author{
İrem BEKAR ${ }^{1 *}$, İpek ÖZPINAR², Şebnem ERTAŞ BEŞiR ${ }^{2}$
}

\section{Öz}

Giderek artan turizm faaliyetlerine bağlı olarak kırsal alanların vernaküler özellikleri zamanla değişikliğe uğramıştır. Bu değişimden başta vernaküler yapılar olmak üzere iç mekan ve mobilyaları da büyük oranda etkilenmiştir. Değişim çok yönlü bir kavramdır. Bu süreçte; vernaküler mobilyalar özgün karakterini koruyup geliştirerek sürekliliğini sağlayabileceği gibi özgün karakterini kaybederek yok olabilmektedir. Vernaküler mobilyanın değişimi süreçlerinin belirlenmesi için onu oluşturan özelliklerin incelenmesi ve bu özelliklerin zamanla oluşturduğu anlamının değerlendirilmesi gerekmektedir. Kırsal alanların turizm etkisiyle değişiminde bu iki farklı olgu transformasyon ve deformasyon olarak tanımlanmaktadır. Çalışmada vernaküler mobilyada yaşanan olumsuz değişimler 'deformasyon' kavramı üzerinden ele alınmış; turizm hareketlerine bağlı olarak deformasyona uğrayan vernaküler sürdürülebilirliğinin gerekliliğine ve önemine dikkat çekmek amaçlanmıştır. Bu kapsamda yapılan literatür araştırması ile değişim türleri belirlenmiş ve mobilyada yaşanan deformasyonlar sosyokültürel etkenlerden kaynaklı deformasyon, ekonomik etkenlerden kaynaklı deformasyon, işlevsel değişimlerden kaynaklı deformasyon ve anlamsal deformasyon olmak üzere dört başlıkla irdelenmiştir. Anahtar Kelimeler: Kırsal Turizm, Vernaküler Mobilya, Değişim, Deformasyon.

\section{Deformation Concept in Rural Tourism and Varnacular Furniture Interaction}

\begin{abstract}
Due to the increasing tourism activities, the vernacular characteristics of rural areas have changed over time. The interior space and furniture, especially the vernacular structures, have also greatly affected by this change. Change is a multifaceted concept. In this process; Vernacular furniture can maintain and improve its original character, or it can disappear by losing its original character. In order to determine the change processes of vernacular furniture, it is necessary to investigate the features that make up it, and also the meaning of these features over time should be evaluated. In the change of rural areas with the effect of tourism, these two different phenomena are defined as transformation and deformation. In the study, the negative changes in vernacular furniture were handled through the concept of 'deformation'; It is aimed to draw attention to the necessity and importance of the sustainability of the vernacular, which undergoes deformation due to tourism movements. In this context, the types of change were determined by the literature research and the deformations in the furniture were examined under four headings: deformation due to sociocultural factors, deformation due to economic factors, deformation due to functional changes and semantic deformation. Keywords: Rural Tourism, Vernacular Furniture, Change, Deformation.
\end{abstract}

\footnotetext{
${ }^{1}$ Karadeniz Teknik Üniversitesi Mimarlık Fakültesi, İç Mimarlık Bölümü, Trabzon TÜRKiYE

${ }^{2}$ Akdeniz Üniversitesi Mimarlık Fakültesi, İç Mimarlık Bölümü, Antalya TÜRKiYE

*ilgili yazar/Corresponding Author: irembekar@ktu.edu.tr 


\section{Giriş}

Dünyanın en büyük ve en hızlı gelişen endüstrilerinden biri olan turizm, insanların sürekli bulundukları yer dışında devamlı olarak yerleşmemek kaydıyla serbest bir ortam içinde, dinlenme, gezi, merak, din, sağlık, spor, eğlence gibi çeşitli amaçlarla veya aile ziyareti, seminerlere katılmak gibi sebeplerle, yaptıkları seyahatlerden, ortaya çıkan iş ve işleri kapsayan, bir tüketim ve sosyal olay olarak tanımlanmaktadır (Oral, 2005; Yılmaz ve Güler, 2017: 18). Turizm, insana hizmet etmenin dışında insan emeğine dayalı bir ticari sektör olarak ön plana çıksa da; turizmin doğduğu, geliştiği bir doğal veya kültürel çevre bulunmaktadır. Bu özellikler aracılığıyla turistlere hizmet verilerek gelir elde edilmekte ve dolayısıyla turizmin geleceği de bu alanların doğru kullanımına bağlı kalmaktadır (Soykan, 1999: 67). Günümüzde ise turizm faaliyetlerindeki talepler değişiklik göstermiş ve kitle turizminde olduğu gibi kıyılara değil, bundan farklı olarak ülkelerin iç ve kırsal yerlerine doğru yönelmiştir (Çetin vd., 2017: 138).

Kırsal çevreler; geçmişte ve günümüzde, bölgeye özgü özellikleriyle kent insanının ilgisini çekmektedir. Turistler için farklı bir anlam ve çekicilik ifade eden kırsal alanlar, gittikçe rekreasyon intiyaçlarına cevap vermektedir. Özellikle kırsal yaşam biçiminin insanlara çekici gelmesi, stres yaratacak sınırlamaların olmayışı, kişilerin kendilerini özgür hissetmesini sağlayacak olanakların varlığı gibi birçok etken kırsal alanlara ziyaretleri arttırmış, böylece 'kırsal turizm' denen bir turizm türü ortaya çıkmıştır (Soykan, 1999: 68). Kırsal turizmi en çekici kılan özelliklerin başında bölgenin vernaküler özellikleri gelmektedir.

Rudofsky (1964) vernaküler terimini kültürler arası farklılaşan, ülkeden ülkeye değişen anlamında kullanmaktadır. Vernaküler terimi informal, spontane, akademik olmayan, özgün, popüler, köye ait, zanaatkar işi, resmi olmayan, anonim ve yerel gibi birçok anlamda kullanılmaktadır. Ayrıca vernakülerlik, belirli bir ülke veya bölgedeki insanlara, çevreye, yaşayış biçimine, geleneklerine ve iklim şartlarına göre değişen spesifik, yerel, lokal ve ortak şeyler anlamında kullanılmaktadır (Eray ve Kutlu, 2021: 71; İbiş, 2019: 1). Vernaküler kavramı bölgede yer alan doğal ve yapay tüm özellikleri ifade etmektedir.

Kırsal turizm zamanla bölgenin vernaküler özelliklerini de etkilemekte ve değiştirmektedir. Bunlar arasında vernaküler mimari kadar iç mekan ve mobilyalar da değişime uğrarlar. Değişim sürecinde nesne ya da kavram transformasyona uğrayarak önceki haline göre sürekliliğini koruyabileceği gibi deformasyona uğrayarak sürekliliğini kaybedebilir. Bu değişimler sonucu nesne veya kavram 'var' olur ya da 'yok' olur. Değişim süreçleri birbirine indirgenemez (Birik, 2011: 57). Transformasyon ve deformasyon kavramını ortaya çıkaran olgu mekanların zaman süreci içerisinde birçok farklı etkenle girdiği etkileşimdir. Kırsal alanlarda bu etkileşimi sağlayan en büyük etkenlerden biri ise kırsal turizmdir.

Kırsal turizm ile beraber gelen değişim; bölgeye birçok yönden katkı sağlayabileceği gibi değişimin türüne bağlı olarak, yapılan bilinçsiz müdahalelerle doğal ve yapılı çevrenin özgün karakterini oluşturan diğer unsurlara zarar verebilmektedir. Çalışmada kırsal turizm ile birlikte vernaküler yaşamın önemli bir göstergesi olan mobilyaların uğradığı değişimler ele alınmıştır. Bu kapsamda transformasyon ve deformasyon konularına değinilerek vernaküler mobilyalarda deformasyon konusuna odaklanılmış ve vernaküler mobilyaların sürdürülebilirliğinin önemine ve gerekliliğine dikkat çekmek amaçlanmıştır. 


\section{Kırsal Turizm ve Sürdürülebilirlik}

Kentleşmenin yaşam tarzını standartlaştırması ve kırsal bölgelerdeki yerel özellikleri ortadan kaldırması günümüz dünyasının en büyük sorunlarından biri haline gelmiştir. Hızlı kentleşmenin insana ve çevreye umarsız devam eden günlük akışı insanoğlunu fırsat buldukları zamanlarda kendini doğa ile baş başa kalabileceği alanlara yönlendirmesine neden olmuştur (Çetinkaya Karafakı ve Yazgan, 2012: 55). Böylece boş zamanlarını değerlendirebileceği, insanların temel intiyaçlarını karşılayabileceği, sosyal faaliyetlerde bulunulabileceği bir zaman dilimi gereksinimi ortaya çıkmıştır. Turizm hareketlerine bağlı olarak gelişen bu faaliyetler başlarda kitle turizmi olarak ortaya çıksa da fiziksel, kültürel ve sosyal özellikleri ile farklılaşan yerleri merak etme, gezme, görme, tanıma eylemler son zamanlarda yerini doğaya ve yerli halka saygılı alternatif turizm yaklaşımlarına bırakmıştır. Kırsal yaşama dair soyut veya somut varlıkların değerlendirildiği, yöresel ürünlerin ve tarımsal faaliyetlerin değer kazandığı, kültürel unsurların yerel düşünce ve doğa ile birlikte modellendirildiği kırsal turizm, bu anlamda öne çıkan faaliyetlerin başında gelmektedir (Üzümcü vd., 2015: 92; Çetin vd., 2017: 138). Çevre dostu, gittiği bölgede yaşayan yerli halkın kültürel değerlerine, inançlarına, geleneklerine saygılı, yeni deneyimlere açık bir turizm çeşidi olan kırsal turizm günümüzde tercih edilen bir turizm türü olmuştur (Çetinkaya Karafakı ve Yazgan, 2012: $55)$.

Kırsal turizme olan ilginin günden güne artmasıyla beraber yörenin özelliklerine göre şekillenen vernaküler çevre ve vernaküler ürünler daha önemli ve ilgi çekici hale gelmiştir. Vernaküler mimari geniş anlamıyla uzman mimarların müdahalesi olmaksızın tecrübe ve deneyime dayalı bilgiyle inşa edilmiş yapılar ve ürünlerdir (Arboleda, 2006). Kırsal alanlarda vernakülerlik kavramı doğal çevre başta olmak üzere insanın katkı verdiği, emeği ve yaratıcılığının ürünü olan yapay çevre, mimari yapılar, iç mekan ve mobilyaları da içermektedir (Şekil 1). Bu unsurların tümü kırsal turizm açısından önemli bir kaynak olmakla beraber sürdürülebilirliğinin sağlanması da önemli bir konu olarak karşımıza çıkmaktadır.

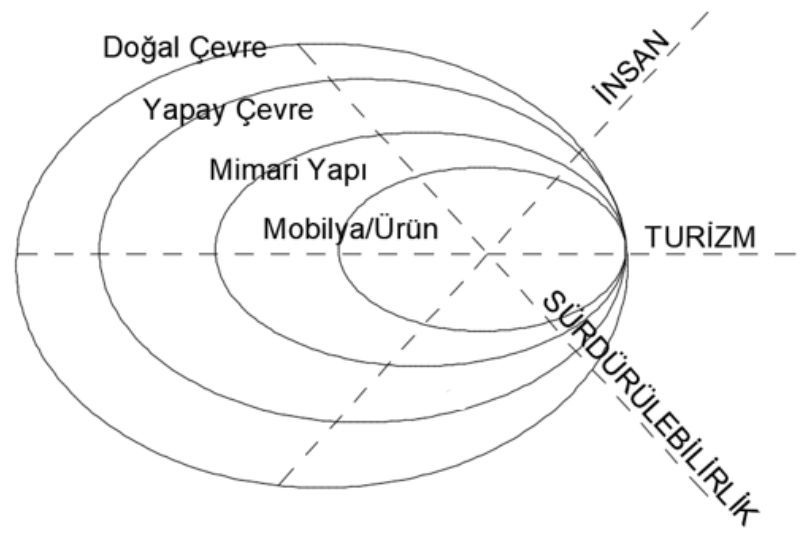

Şekil 1: Vernaküler çevre-turizm ilişkisi (Şekil yazarlar tarafından oluşturulmuştur.)

Son dönemlerde kırsal turizme olan talebin artmasının bir sonucu olarak vernaküler çevrede değişiklikler meydana gelmektedir. Yöre halkı ve yerel yönetimler bölgeyi tanıtma ve çoğunlukla ekonomik gelir elde edebilme amaçlı alternatif çözümler aramaya başlamıştır. Artan turizm hareketlerine bağlı olarak insanlar konutlarını turistlere hizmet edecek şekilde işlevlendirerek yeniden düzenlemiştir. Bu faaliyetlerden başta vernaküler yapılar olmak üzere iç mekan ve mobilyalar da büyük oranda etkilenmiştir. Meydana gelen değişimler fırsatlar sunabileceği gibi yanlış müdahalelere maruz kaldığında tehdit de oluşturabilmektedir. Yapılan yanlış müdahaleler orijinal dokuya zarar vererek vernaküler çevrenin zamanla özgün kimliğini kaybetmesine sebep olmaktadır. 
Kırsal turizmin sürdürülebilirliği turistik kalkınma ile zarar görmek yerine yararlı olan vernaküler çevre, toplum ve kültürlerle uyum içinde işlenen bir süreç ile mümkündür (Özgüç, 2017: 181; Güneş, 2008: 28; Kaypak, 2012: 21). Kırsal turizm planlamasında, gelişiminde ve işleyişinde turizmin tüm alanlarıyla ilgili genel bir kavram haline gelen sürdürülebilirlik son yıllarda odaklanılan bir konudur.

Sürdürülebilirlik çerçevesinde etkili bir kırsal turizm gelişiminden söz edebilmek için vernaküler çevre ve turizm birbiriyle ilişkili olmalı ve doğru yönetilmelidir. Aransson (1994), doğal ve kültürel kaynakların bir sınırı olduğunu, bilinçsiz ve aşırı tüketimde zarar göreceğini belirtmiştir. Günümüzde kırsal turizm etkisiyle bölgeden ekonomik boyutta daha fazla yararlanma çabasına bağlı olarak turizm aktivitelerinin çeşitlenmesi ve turizme katılan insan sayısının artması kırsal bölgelerin tahrip olmasına ve bu bölgelerdeki doğal ortamın hem sosyal hem de kültürel açıdan bozulmasına neden olmaktadır (Pelit vd. 2015: 44). Bu kapsamda, kırsal turizmin sürdürülebilirliği için destinasyonun sahip olduğu vernaküler değerlerin doğru bir şekilde belirlenmesi ve sürdürülebilirlik anlayışı içerisinde korunması ve yönetilmesi gerekmektedir (Yıldırım Saçılık ve Toptaş, 2017: 109). Doğal çevreden yapılı çevreye, mimariden ürüne geniş bir kapsamı içerisinde barındıran vernaküler değerler kırsal turizmden olumlu veya olumsuz olarak farklı ölçeklerde etkilenmektedir.

\subsection{Vernaküler mobilyanın sürdürülebilirliği}

Mobilyalar, bir kimliği temsil etmenin yanında, onu üreten, kullanan insanların ve bölgenin kültürel özelliklerini ifade eden bilgileri de taşımaktadır. Bu özellikler toplumun inancı, gelenekleri ve etnik yapısıyla bulunduğu coğrafi konumu ile ilişkilendirilebilmektedir. Genel olarak mobilya, farklılaşma, grupların toplumsal özelliklerine bağlı olarak çeşitli sosyo-kültürel ortamlara göre farklı sistemler oluşturmaktadır. Her grubun, toplumun veya toplum kesiminin yaşama biçiminin özellikleri, bu grubu ya da kesimi diğerlerinden ayırt etmeyi sağlamakta; her toplum kendi özellikleri doğrultusunda mobilyalar üretmekte, almakta, kullanmakta ve atmaktadır (Özçam, 2013). Mobilyanın formundan malzemesine, süslemelerinden yapım tekniğine kadar tüm özellikleri bulunduğu bölgenin çeşitli etkenleri ile şekillenmektedir.

Günümüzde kırsal alanlarda turizm kaynaklı genellikle vernaküler mimariye dayalı işlevsel değişikliklere yönelik uygulamalar gerçekleşmektedir. Yeniden işlevlendirme sürecinde vernaküler dokuyu yansıtan unsurların bütünü ele alınmalıdır. Bu kapsamda vernaküler mobilyalar da kırsal alanların kültürel karakterini tanımlamada en önemli araçlar arasındadır.

Sanayileşmeyle birlikte Dünyada ve Türkiye'de vernaküler mobilyalar, yerini günümüzde hızlı üretim ve fabrika ürünü mobilyalara bırakmıştır. Bu nedenle, her yörenin farklı tasarım anlayışıyla usta-çırak ilişkisine dayalı olan vernaküler mobilya üretimi zamanla ustası ile beraber yok olmaktadır. Vernaküler kavramı günümüzde hala varlığını sürdüren bir kavram olmasına karşın çoğunlukla vernaküler mimarinin devamlılığı üzerine yoğunlaşılmakta; vernaküler mobilya açısından yeterli faaliyetler bulunmamaktadır (İbiş, 2019: 62). Bu nedenle kırsal turizm ve sürdürülebilirlik arakesitinde; geçmişin ipuçlarını, bölgenin yaşam şeklini, kültürel izlerini büyük oranda yansıtan vernaküler mobilyaların yeri, önemi ve sürdürülebilirliğinin gerekliliği bir kez daha ortaya çıkmıştır.

Birçok farklı değişken doğrultusunda vernaküler mobilyaların sürdürülebilirliği çevresel koşullardaki değişimler, turizm baskısı, tüketici tercihleri gibi etkenler çerçevesinde sosyokültürel, işlevsel, ekonomik ve anlamsal değişim olmak üzere dört farklı adımda tanımlanabilir (Çizelge 1). 
Çizelge 1: Sürdürülebilirlik kapsamında incelenen değişimler (Çizelge yazarlar tarafından oluşturulmuştur.)

\begin{tabular}{|c|c|}
\hline Sosyokültürel değişim & $\begin{array}{l}\text { (Oktay, 2017), (Yazar, 2010), (Aydın ve Okuyucu, } \\
\text { 2009), (Qtaishat vd., 2020), (Vellinga, 2014), (Scerri } \\
\text { vd., 2016), (lonela, 2015), (Sharma, 2011), (Altan ve } \\
\text { Özsoy, 2017), (Kuter ve Ünal, 2009). }\end{array}$ \\
\hline İşlevsel değişim & $\begin{array}{l}\text { (Oktay, 2017), (Yazar, 2010), (Kıvılcım, 2019), (Bilgin } \\
\text { vd., 2019), (Can, 2007), (Jingjuan ve Dawai, 2015). }\end{array}$ \\
\hline Ekonomik değişim & $\begin{array}{l}\text { (Oktay, 2017), (Yazar, 2010), (Vellinga, 2014), (Scerri } \\
\text { vd., 2016), (lonela, 2015), (Sharma, 2011), (Öter ve } \\
\text { Ünal, 2011), (Bilgin vd., 2019). }\end{array}$ \\
\hline Anlamsal değişim & $\begin{array}{l}\text { (Kalfaoğlu Hatipoğlu ve Koç Aytekin, 2020), } \\
\text { (Parmaksız, 2019), (Bali, 2020), (Koçhan, 2003), } \\
\text { (Vázquez Loaiza, 2019), (Carballo ve Carmelo, 2017). }\end{array}$ \\
\hline
\end{tabular}

Sürdürülebilirlik kapsamında ele alınan değişimler, günlük yaşamın dönüşümüyle birlikte hızlanmakta, vernaküler çevre ile birlikte mobilyaları da etkilemektedir. Özellikle bu hızlanmada önemli bir tetikleyici unsur olan turizm faaliyetleri de önde gelmektedir. Ancak vernaküler mobilyalarda yaşanan değişim her zaman olumlu anlamda olmayabilir; özellikle süreçte doğru değerlendirilemediğinde, deformasyona uğramakta ve zamanla yok olmaktadır.

\section{Vernaküler Mobilya ve Değişim}

Vernaküler mobilyanın değişim süreçlerinin belirlenmesi için onu oluşturan özelliklerin incelenmesi ve bu özelliklerin zamanla oluşturduğu anlamının değerlendirilmesi gerekmektedir. Değişim çok yönlü bir kavramdır. Vernaküler mobilya değişim sürecinde turizm ile birlikte özgün karakterini koruyup geliştirerek sürekliliğini sağlayabileceği gibi özgün karakterini kaybederek yok olabilmektedir. Bu iki farklı olgu 'transformasyon' ve 'deformasyon' olarak karşımıza çıkmaktadır.

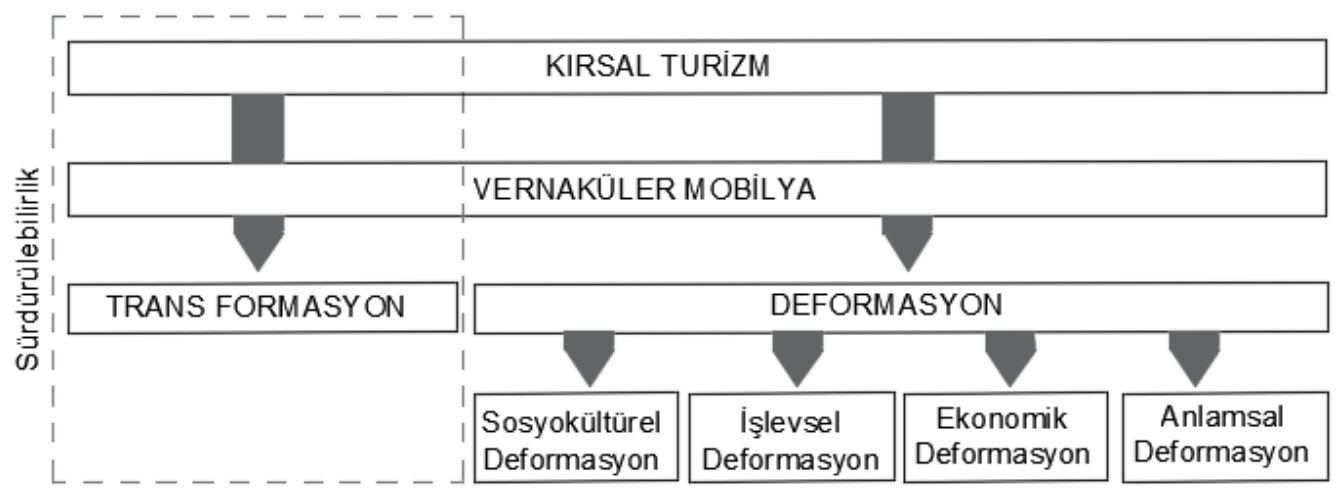

Şekil 2: Kırsal turizm ile vernaküler mobilyanın değişimi (Şekil yazarlar tarafından oluşturulmuştur.)

'Transformasyon', var olan biçim ya da olgunun değişerek sürekliliğinin devam etmesi anlamına gelerek olumlu bir durum olarak incelenirken, 'deformasyon'; sürekliliğin ortadan kalkarak var olan biçim ya da olgunun niteliklerini terk etmeye başlaması ya da yok olması anlamına gelerek olumsuz bir durum olarak incelenmektedir (Birik, 2011: 55). $\mathrm{Bu}$ doğrultuda, transformasyon mobilyanın sürekliliğini koruyarak değişimini ifade etmekte, deformasyon mobilyanın kültürel, anlamsal veya işlevsel yönlerden sürekliliğini kaybederek gerçekleşen değişimini ifade etmektedir. Vernaküler mobilya özelliklerinin 
zaman içerisindeki durumu değişim süreçlerinin tanımlanarak deformasyon veya transformasyon olarak isimlendirilmesinde belirleyicidir.

Çalışmada kırsal alanların turizm etkisiyle değişimde vernaküler mobilyada yaşanan olumsuz değişimler 'deformasyon' kavramı üzerinden ele alınmış, sürdürülebilirlikle ilişkisi incelenmiştir. Bu kapsamda mobilyadaki deformasyon; sosyokültürel etkenlerden kaynaklı deformasyon, ekonomik etkenlerden kaynaklı deformasyon, işlevsel değişimlerden kaynaklı deformasyon ve anlamsal deformasyon olmak üzere dört başlıkla irdelenmiştir.

\subsection{Mobilyada sosyokültürel etkenlerden kaynaklı deformasyon}

Turizmin temelde toplumsal bir olay olması sebebiyle toplumsal yapı ve yaşam üzerinde etkileri oldukça fazladır (Yazar, 2010: 177). Turizm doğası gereği hem turistlerin hem de ziyaret edilen alanda yaşayan nüfusun yapısını etkilemektedir. Turizmin neden olduğu sosyal etkiler kırsal alanları ve çevresinde yaşayan kent sakinlerinin yaşam kalitesini değiştirmektedir (Oktay, 2017: 29). Böylece kültürel birikimi ile ön plana çıkan kırsal alanlar "turistik tüketimin" gözetildiği bir mekanlar haline gelmeye başlamıştır. Turistik tüketim, değişen tüketim alışkanlıkları ile birlikte fiyat, gelir düzeyi, ulaşım olanakları, arz potansiyeli, reklam ve tanıtım faktörlerinden etkilenerek değişir (Özen, 2009). Bu değişimden vernaküler mobilyalar da aşağıda belirtilen sosyokültürel unsurlar nedeniyle gerçekleşmektedir.

- Kırsal alanlarda çevreye getirilecek hizmetlerin yerel halk düşünülmeden sadece turist odaklı düşünülmesi kişilerin kendi çevrelerine yabancılaşmasına neden olmakta ve insanlar çevrelerini şekillendirirken daha modern mobilyalara ilgi duymaktadır. Bunun bir sonucu olarak vernaküler mobilyalar yerini fabrika ürünü mobilyalara bırakmıştır. Şekil 3'te geleneksel özelliklere sahip bir konutta kullanılan fabrika ürünü mobilyalar görülmektedir.
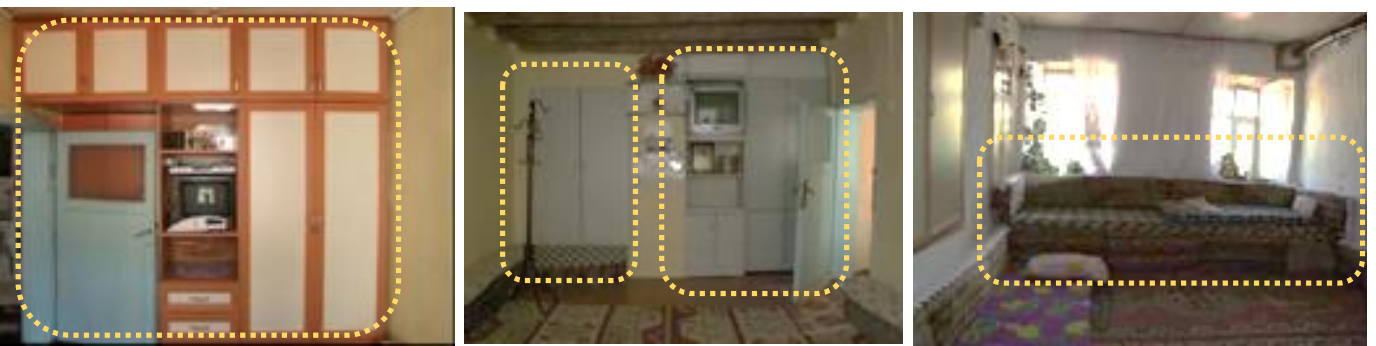

Şekil 3: Konutta kullanılan mobilyalardaki değişim (Taş, 2015)

- Turizmin faydalandığı temel öğelerden biri de ulaşımdır. Kırsal turizmin yoğunlaştığı bölgelerde ulaşımın da gelişmesi bölge halkının kolaylıkla kente gidebilmesine imkan tanımıştır. Bunun bir sonucu olarak insanlar kolaylıkla modern ve yeni mobilyalara ulaşmasıyla mobilya tercihleri değişeme uğraşmıştır. Böylece vernaküler mobilyalar kullanılmamaya ve zamanla yok olmaya başlamıştır.

- Turizm ile birlikte yükselen nüfus hareketleri, birey sayısının artmasını ve daha fazla mobilya intiyacını doğurmuştur. Bu da yöre insanını fabrikasyon mobilyalara yönlendirmiştir.

- Özellikle kültürel kimlik duygusunun tam yerleşmediği kırsal alanlarda yerel halkın, gelen turistlerin her türlü eyleminden etkilenebilmesi sonucu kültürel yozlaşmaya uğradığı görülmektedir (Yazar, 2010: 179). Doğan (1987), bu olayı Bugnicourt'dan yaptığı alıntı ile şu şekilde desteklemekte ve "yerlilerin turistleri taklit etmesi sonucunda yerli kültürün yoksullaştığı, ve turistlerle ilişkilerin yerlilerde aşağılık duygularının oluşmasına yol açtığını belirtmekte; bu durumu 
yeni bir sömürgecilik olarak" tanımlamaktadır. Bu durum aynı zamanda yerel halkın mobilya tercihlerini etkileyerek kendi vernaküler değerlerini göz ardı etmesine de sebep olmaktadır.

\subsection{Mobilyada işlevsel değişimlerden kaynaklı deformasyon}

Kırsal turizm etkisiyle kırsal alanlarda bulunan yapılar farklılaşmakta ve vernaküler yapılar farklı işlevlere hizmet verecek şekilde kullanılmaktadır. Bu değişim sürecinde kırsal turizme hizmet amacıyla yapılan yanlış uygulamalar vernaküler dokuya zarar verebilmekte ve bozulmasına neden olabilmektedir. Bu nedenle kırsal alanlardaki yeniden işlevlendirme çalışmaları sürecinde bölgenin fiziksel ve sosyokültürel özelliklerinin hasara uğramadan yürütülmesi önemli bir konudur. Sürecin vernaküler mobilyalar açısından aşağıda belirtilen nedenlerle oluştuğu söylenebilir.

- Turistik bölgelerde ziyaretçi talepleri ön planda tutularak işlevsel yapının yeniden şekillendirilmesi "yerinden edilme" sorunlarına yol açabilmektedir (Oktay, 2017: 29). Bu terim; konut işlevi dışında kullanılan yapı sakinlerinin farklı yerlerde yaşamalarında zorlanmaları anlamına gelmektedir. Vernaküler mobilyalar özelinde ele alındığında ise başka işlevlere hizmet etmek üzere düzenlenen yapılardaki mobilyaların yerlerini günümüz mobilyalarına bırakması olarak karşııı bulmaktadır. Bu da vernaküler mobilyanın zamanla yok olması ile sonuçlanabilmektedir.

- Vernaküler mobilyanın bir diğer kullanımı ise yapının işlevi değişse bile mekanda bir dekor öğesi olarak kullanılmasıdır. Fakat bu aşamada mobilyanın restore edilme süreci doğru yönetilmelidir. Mobilyanın özgünlüğüne zarar verecek boyama, örtme, eksiltme vb. uygulamaların yapılması deformasyona uğraması ve zamanla yok olabilmesine neden olabilmektedir. Şekil 4 'te donatıların boyanarak özgün dokularının yok edildiği örnekler görülmektedir.
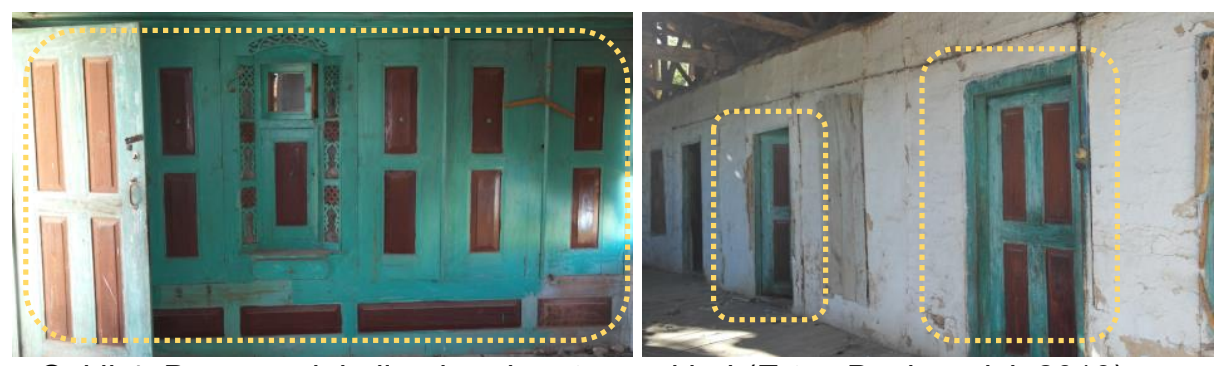

Şekil 4: Boyanarak kullanılan donatı örnekleri (Ertaş Beşir arşivi, 2019)

- Yeniden işlevlendirme çalışmalarında yapısal ve mekansal özellikler daha ön planda tutulmakta ve vernaküler mobilyalara yeterince değer verilmemektedir. Bu da vernaküler mobilyanın zamanla yok olma tehlikesini doğurmaktadır. Şekil 5'te bir konutta yer alan özgün mobilyaların onarılarak kullanıldığı örnekler yer almaktadır.
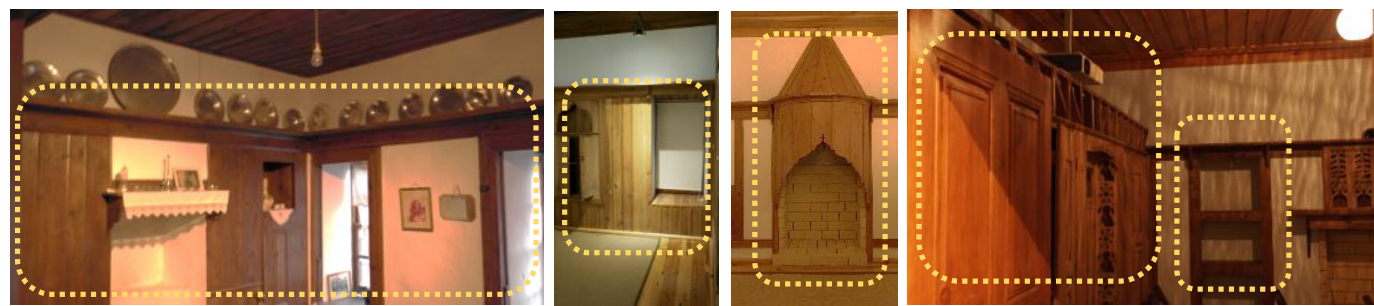

Şekil 5: Mevcut halinden alınıp onarılarak kullanılan elemanlar (Ertaş Beşir arşivi, 2019) 
- Kırsal turizmin etkisiyle yaşanan yoğunluk ve yeniden işlevlendirilen yapıların kullanımında da kendini göstermektedir. Vernaküler mobilyaların da içerisinde olduğu mekanlardaki bu yoğun ve aşırı kullanım zamanla mobilyanın fiziksel olarak deformasyona uğramasına neden olabilmektedir.

\subsection{Mobilyada ekonomik etkenlerden kaynaklı deformasyon}

Kırsal alanlarda turizmin etkisiyle ekonomik nedenlerden kaynaklı değişimler yaşanmaktadır. Ashworth ve Page (2011) 'e göre, turizmin ekonomik etkileri olumlu olabileceği gibi olumsuz sonuçlar da doğurabilmektedir. Bu sonuçlar kırsal çevre içerisinde vernaküler mobilyanın sürdürülebilirliğine aşağıdaki nedenler açısından etki etmektedir.

- Harvey'e (2008) göre, turizm destekli yenileme projeleri yerel halkın daha az maliyetli, ekonomik alanlara çözümler aramasına neden olmaktadır (Oktay, 2017: 29). Yeni işlevlerine hizmet etmek üzere konaklama, gıda, ulaşım, yeme- içme gibi amaçlar için düzenlenen mekanlarda doğan mobilya intiyacı ekonomik sebepler nedeniyle yerini daha az maliyetli fabrika ürünü mobilyalara bırakmıştır. Bu durum aynı zamanda vernaküler mimari ve içerisinde kullanılan mobilyaların uyumsuzluğu ile de sonuçlanmaktadır. Şekil 6'da müze olarak işlevlendirilen bir konutta kullanılan mobilyalar görülmektedir.
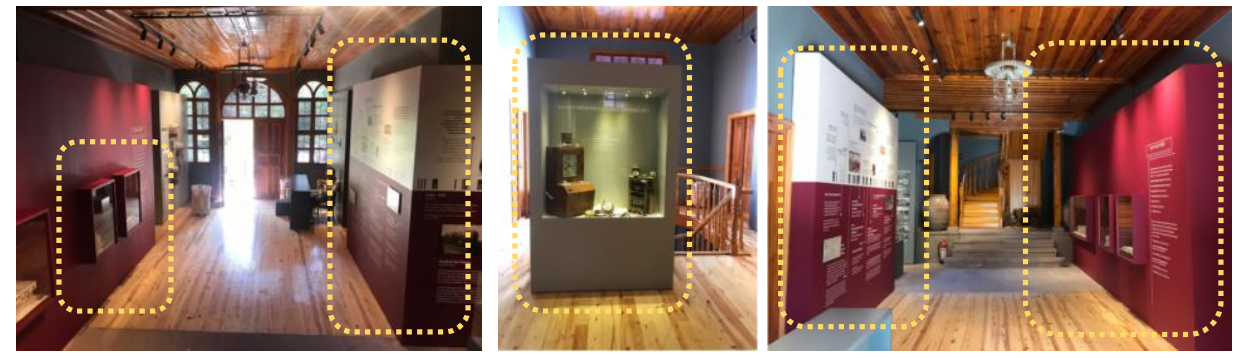

Şekil 6: Müze olarak işlevlendirilen mekanda kullanılan mobilyalar, Sille Müzesi (Ertaş Beşir arşivi, 2019)

- Vernaküler mobilyalar kırsal turizm etkisiyle ilginin turizm sektörüne kaymasına neden olmuş; vernaküler mobilya üreticisi ustalar artık gelir elde etme yolunu turizme yönelik faaliyetlerde aramıştır. Bunun bir sonucu olarak zaten az olan vernaküler mobilya üretimi önemini tamamen kaybetmeye başlamıştır.

\subsection{Mobilyanın anlamsal deformasyonu}

İnsanlar onları çevreleyen mekan ve mobilyalara zamanla ve yaşadığı anılarla birlikte anlam yüklerler. Böylece her mobilya kullanıcının bir yansıması haline gelir ve hafızalarda yer edinir. Bu nedenle mobilyalar sadece işlevsel özellikleri ile değil kullanıcısının ona yüklediği anlamsal değerleri ile de var olurlar. Kırsal turizm ile vernaküler mobilyaların bellekteki anlamsal sürekliliği de sekteye uğramış, imge ve bellek birbirinden uzaklaşarak zaman ve deneyim süreksizleşmiştir (Parmaksız, 2019: 13).

Çoğunlukla insan emeğinin, bilgisinin ve yaratıcılığının bir ürünü olan vernaküler mobilyalar ise bölgenin coğrafi, iklimsel, ekonomik, kültürel özelliklerinin bir yansımasıdır. Onu yapan usta ve kullanıcısı ile olan etkileşimi mobilyanın bir anlam kazanmasını sağlar. Mobilyanın zaman içerisinde uğradığı kültürel, ekonomik veya işlevsel değişimlerle birlikte soyut veya somut olarak hasara uğraması onun fiziksel özelliklerinin dışında anlamsal değerinin de kaybolması ile sonuçlanmaktadır. Bu nedenle geçmişi ve kullanıcısı hakkında bilgi veren bu mobilyaların sürekliliğinin sağlanması aşağıda belirtilen gerekçeler üzerinden ele alınabilir. 
- Kırsal alanlarda turizmin yaygınlaşması ile değişen talepler ve ilgi alanları geçmişi ile beraber var olan vernaküler mobilyaların işlevsel ve görsel özellikleri açısından yetersiz görülmesine neden olmuş ve kullanımı azaltmıştır. Kullanılmayan mobilyalar ise konutların bir köşesinde unutulmaya mahkum bırakılmış ve hem fiziksel özelliklerine yansıttığı kültürel değerler hem de kullanıcısının ona yüklediği anlamsal değer ile zamanla yok olmuştur.

- Mobilyaların kullanıcısı ile olan ilişkisi doğrultusunda temsil ettiği anlam kişiden kişiye değişmektedir. Bölgede yaşayan insanın ona kattığı anlam ile turistik amaçla bölgeyi ziyarete gelen kişiler için mobilyanın ifade ettiği anlam kişilerin kültürel özelliklerinin etkisiyle farklılık gösterir. Mobilyanın asıl kullanıcısı bölgenin kültürel değerleri ile bir anlama bürünürken, bölge dışı insanlar için daha çok biçimsel özellikleri ile ön plana çıkarlar. Özellikle turizm nedeniyle yerli halk dışında farklı şehirlerden gelen işletmeciler, bu anlamsal ilişkiyi kuramazlar. Bu da mobilyanın anlamının bellekteki yerini zedelemektedir.

\section{Değerlendirme ve Sonuç}

Kırsal turizm zamanla bölgenin vernaküler özelliklerini de etkilemekte; mobilyalar da bunlardan zamanla soyutlanarak değişime uğramaktadır. Bu süreçte nesne ya da anlam transformasyona uğrayarak önceki haline göre sürekliliğini koruyabileceği gibi deformasyona uğrayarak sürekliliğini kaybedebilir. Bu doğrultuda saptanan sonuçlar aşağıda sıralanmıştır.

- Kırsal turizm faaliyetlerinde turist odaklı yaklaşımlar yöre halkının vernaküler mobilyaya bakış açısını ve kullanımını olumsuz yönde etkileyebilmektedir.

- Turistlerin gittikleri bölgelerde yöre halkı ile olan olumsuz etkileşimleri vernaküler çevrenin zarar görmesine ve kentsel yaşama yönelik ürünlerin yaygınlaşarak vernaküler mobilya karakterinin zamanla yok olmasına sebep olabilmektedir. $\mathrm{Bu}$ da kırsal alanlardaki özgün vernaküler mobilyaların yerine fabrika ürünü mobilyalar kullanılması ve kırsal bölgelerdeki özgün değerlerin zayıflayarak birbirine benzemesi ile sonuçlanmaktadır.

- Turizm odaklı gelişmeler yöre halkının ekonomik açıdan faaliyetlerinin değişmesine de neden olmaktadır. Mobilyalar önceden bulunduğu bölgedeki ağaçtan, ustasının teknik bilgisinden, el emeğinden meydana gelirken daha düşük maliyetli mobilyalara olan eğilim, vernaküler mobilyanın üretimini azaltmakta ve yerini tek tip fabrika ürünü mobilyalara bırakmaktadır.

- Kırsal çevrelerde fabrika ürünü mobilyalara artan ilgi mobilya ustalarının artık üretmemesine ve usta-çırak ilişkisinin de azalarak vernaküler mobilyaların yapım tekniği, malzemesi, süsleme özellikleri gibi değerlerinin unutulup yok olmasına neden olmaktadır.

- Kırsal turizm etkisiyle yapılan yeniden işlevlendirilme çalışmalarında vernaküler mobilyalar göz ardı edilmekte veya kullanım dışı bırakılmaktadır. Vernaküler mimarinin yeni bir işlevle kullanılmasına yönelik çalışmalarda vernaküler mobilyalar mekanla birlikte düşünülmeli; kullanım dışı veya yanlış kullanıma maruz kalmaktansa değerlerini arttırıcı ve önemini vurgulayıcı uygulamalarla ele alınmalıdır.

Bulunduğu bölgenin kültürel değerlerinden, geçmişinden, üreten usta ve kullanıcı özelliklerinden izler taşıyan vernaküler mobilyalar, günümüzde kırsal turizm vb. unsurların etkisiyle yanlış uygulamalar veya bilinçsiz kullanımlar sonucu deformasyona uğramaktadır. Vernaküler mobilyaların geri planda kalması ve yok olması önlenebilir bir durumdur. Bu nedenle yerel halkın, bölgeyi ziyarete gelen turistlerin ve yerel yönetimlerin bu konuda önlem almaları gerekmektedir. 


\section{Kaynaklar}

Altan, Hasan ve Karaderi Özsoy, Şefika, "Tarihsel Süreçten Günümüze Büyük Han ve Yeniden Kullanıma Adaptasyonda Sosyokültürel Sürdürülebilirlik Bağlamında Mekan İşlevlendirilmesi", The Turkish Online Journal of Design Art and Communication, 7(4), 2017, s. 634-654.

Aransson, Lars, "Sustainable Tourism System: The Example of Sustainable Rural Tourism in Sweden", Journal of Sustainable Tourism, 2(1/2), 1994, pp. 81-92.

Arboleda, Gabriel, http://www.ethnoarchitecture.org/web/articles/article/449, 2006, [26.01.2017].

Ashworth, G. J. and Page, S. J., "Urban Tourism Research: Recent Progress and Current Paradoxes", Tourism Management, 32.1, 2011, s. 1-15.

Aydın, Dicle; Okuyucu, Ş. Ebru, "Yeniden Kullanıma Adaptasyon ve Sosyokültürel Sürdürülebilirlik Bağlamında Afyonkarahisar Millet Hamamının Değerlendirilmesi", MEGARON, 4(1), 2009, s. 35-44.

Bali, Meltem, "Mekanın Belleği ile Uyumlu Sürdürülebilir Kültür Stratejisi Üretmek: Eyüp Sultan Belediyesi Şehir ve Medeniyet Okulu Örneği”, Milli Kültür Araştırmaları Dergisi, 4(2), 2020, s.43-58.

Bilgin vd., "Physical Changes in World Heritage Sites under the Pressure of Tourism: The Case of Cumalıkızık Village in Bursa", European Journal of Sustainable Development, 8(2), 2019, s. 249.

Birik, Melih, Kentsel Mekanın Değişim Sürecinde Transformasyon ve Deformasyon, Mimar Sinan Güzel Sanatlar Üniversitesi, Doktora tezi, Fen Bilimleri Enstitüsü, İstanbul 2011, s. 228.

Can, Şükran Güneş, A critical assessment for reuse of traditional dwellings as "Boutique Hotels" in Urgup, Master Thesis, Middle East Technical University, 2007, s. 272.

Carballo, Rita R.; Carmelo J. León, "The influence of artistically recreated nature on the image of tourist destinations: Lanzarote's art, cultural and tourism visitor centres and their links to sustainable tourism marketing", Journal of Sustainable Tourism, 26(2), 2017, s.192-204.

Çetin, İbrahim; Polat Üzümcü, Tülay; İçöz, Orhan, "Kırsal Alanlarda Sürdürülebilir Kırsal Turizm ve Kocaeli-Kandıra Kırsal Turizm Gelişimi Modeli”, Erzincan Üniversitesi Sosyal Bilimler Enstitüsü Dergisi, Erzincan 2017, s. 137-156.

Çetinkaya Karafakı, Filiz; Yazgan, Murat E., "Kırsal Turizme Kavramsal Yaklaşım, Kırsal Turizmin Önemi ve Etkileri”, International Journal of Social and Economic Sciences 2(2), 2012, s. 55-58.

Doğan, Hasan Zafer, Turizmin Sosyo-Kültürel Temelleri, Uğur Ofset Matbaacılık ve Ticaret, İzmir 1987, s. 175.

Eray, Saide Selin; Kutlu, İzzettin, "Compact City As A Sustaınable Urban Form Case Of Yazd City Iran", 5th International Congress on Architecture and Design 2021, s. 71-77. 
Güler, Mehmet Emre; Yılmaz, Levent, “Türkiye'de Muhafazakar Değerler Bağlamında Turizm ve Tatil Algısındaki Değişme”, Uluslararası Güncel Turizm Araştırmaları Dergisi, 1(1), 2017, s. 17-25.

Güneş, Gül, “Turizmin Sürdürülebilirliği için Ekoturizm”, Popüler Bilim Dergisi, 15(177), Kasım 2008, s. 28-30.

Harvey, David, "The Right To The City”, New Left Review 53, 2008, s. 23-40.

Ionela, Gavrilă-Pave; Constantin, Bârsan Mircea; Dogaru, Lia-Dorica, "Advantages and Limits for Tourism Development in Rural Area (Case Study Ampoi and MureúValleys)", Procedia Economics and Finance, 32(2015) s. 1050-1059.

İbiş, Bengüsu, Türkiye'de Toplu Konut Üretiminde Dikkate Alınan Vernaküler Tasarım Kriterlerinin Bina Üretim Süreçlerine Bağlı Olarak Değerlendirilmesi, Yüksek Lisans Tezi, ITÜ, Fen Bilimleri Enstitüsü, Mimarlık Anabilim Dalı Proje ve Yapım Yönetimi Programı, İstanbul 2019, s. 199.

Jingjuan, Ji ve Dawai, Xiao, "The Research on Reuse Forms of Traditional Buildings in Villages", 2015.

Kalfaoğlu Hatipoğlu, Hatice ve Koç Aytekin, Çiğdem, "Mimaride Tasarım Kodları ve Anlamsal Sürdürülebilirlik: Dil, Bellek ve Kimlik Tartışması", Kent Araştırmaları Dergisi, 11(31), 2020, s. 1676-1698.

Kaypak, Şafak, "Ekolojik Turizm ve Sürdürülebilir Kırsal Kalkınma”, Karamanoğlu Mehmetbey Üniversitesi Sosyal ve Ekonomik Araştırmalar Dergisi, 2012(1), s. 11-29.

Kıvılcım, Ecehan, "Geleneksel Konutta İşlevsel Dönüşümün Mekânsal Bağlamda İrdelenmesi: Denizli Konyalıoğlu Evi Örneği”, Ege Mimarlık, Haziran 2019, s. 50-55.

Koçhan, Ahmet, "Doğal Çevreyle Kurulan Anlamsal Bağ: Sürdürülebilir Toplu Konut Tasarımı," Yapı Dergisi, sa.256, 2003, s. 49-55.

Kuter, Nazan ve Ünal, H. Emre, "Sürdürülebilirlik Kapsamında Ekoturizmin Çevresel, Ekonomik ve Sosyo-Kültürel Etkileri”, Kastamonu Üniversitesi, Orman Fakültesi Dergisi, 9(2), 2009, s. 146-156.

Oktay, Meltem, Tarihi Kent Merkezlerinde Turizm Sektörünün Ticari Kimlik Üzerindeki Etkisi, Lisans Tezi, Yıldız Teknik Üniversitesi, Şehir ve Bölge Planlama Anabilim Dalı, İstanbul 2017.

Oral, Saime, Otel İşletmeciliği ve Verimlilik Analizleri, Detay Yayıncılık, 5.Baskı, Ankara 2005, s. 496.

Otaishat vd., "Exploring The Socio-Cultural Sustainability of Old and New Housing: Two Cases From Jordan", Sustainable Cities and Society, Volume 61, October 2020, 102250.

Öter, Zafer ve Ünal, Elif, "Somut Olmayan Kültürel Miras ve Turizm Etkileşiminin Beypazarı İlçesinde Yerel Ekonomiye Katkıları", 8. Milletlerarası Türk Halkbilimi Kongresi, Paloma Pasha Resort, Özdere-İzmir, (Kasım 21-24, 2011): 1-17. 
Özçam, Işıl, Biçim Dili ve Iletişim Ekseninde Mobilyanın Sembolleşmesi ve Günümüz Mobilyasının Sembolleşmesinde Rol Oynayan Sosyolojik ve Teknolojik Etkenler, Doktora Tezi, Fen Bilimleri Enstitüsü, MSGSÜ, İç Mimarlık Anasanat Dalı, İstanbul 2013, s. 370.

Özen, Sinem, (2009). Dünya Turizminde Tüketici Tercihlerinde Yaşanan Değişimlerin Konaklama İşletmelerine Yansımaları: Antalya'da Temalı Otel Örnekleri, Yüksek Lisans Tezi, Adnan Menderes Üniversitesi, Sosyal Bilimler Enstitüsü, Aydın 2009, s. 179.

Özgüç, Nazmiye, Turizm Coğrafyası Özellikler ve Bölgeler, Çantay Kitabevi, 9.Baskı, İstanbul 2017.

Parmaksız, Pınar Melis, "Belleğin Mekanından, Mekanın Belleğine: Kavramsal Bir Tartışma”, Bahçeşehir Üniversitesi, İktisadi, İdari ve Sosyal Bilimler Fakültesi, İlef Dergisi, Araştırma Makalesi, 2019, 6(1), s. 7-26.

Pelit, Elbeyi, Baytok, Ahmet ve Soybalı, Hüseyin H., "Sürdürülebilir Turizm Mi? Turizmde Sürdürülebilirlik Mi? Kavramsal Bir Tartışma”, Sosyal Bilimler Elektronik Dergisi, 2015, 6(14), s. 39-58.

Polat Üzümcü, Tülay; Çelik, Aysun; Otar, Serenad; Hacıalioğlu, Ayşegül, "Kırsal Alanların Sürdürülebilir Kırsal Turizm Amaçlı Kullanılması Kocaeli-Kandıra Örneği", Uluslararası Sosyal ve Ekonomik Bilimler Dergisi, 5(2), 2015, s. 92-102.

Rudofsky, Bernard, "Architecture Without Architects: A Short Introduction To NonPedigreed Architecture", UNM Press, 1964, s. 156.

Scerri vd., "The Value Of Architecture To Tourism", University of Technology Sydney, February 2016, s. 21.

Sharma, Krishna, Sustainable Tourism Development Through Sustainable Architecture: A Projected Case Study of Cox's Bazar, Masters Thesis, University of Huddersfield, Bangladesh, 2011.

Soykan, Füsun, "Doğal Çevre ve Kırsal Kültürle Bütünleşen Bir Turizm Türü: Kırsal Turizm”, Anatolia: Turizm Araştırmaları Dergisi, 10(1), 1999, s. 67-75.

Taş, Aslı, Bir konut alanında kültürel değişimin mekansal sürekliliği: Sille/Hacı Ali Ağa Sokağı, Yüksek Lisans Tezi, KTÜ, Fen Bilimleri Enstirüsü, Trabzon, 2015.

Vázquez Loaiza, Juan Pablo; Pérez-Torres, Antonio; Díaz Contreras, Karol Marylin, "Semantic Icons: A Sentiment Analysis as a Contribution to Sustainable Tourism" Sustainability, 2019; 11(17): 4655.

Vellinga, M., Vernacular Architecture: Towards a Sustainable Future, Plenary lectures Vernacular architecture and sustainability: Two or three lessons, 1st Edition, 2014.

Yazar, Burcu, Turizmin Tarihsel Dokulara Etkileri: Antalya Örneği, Yüksek Lisans Tezi, Dokuz Eylül Üniversitesi, Fen Bilimleri Enstitüsü, İzmir 2010, s. 576.

Yıldırım Saçılık, Melahat ve Toptaş, Aytaç, "Kültür Turizmi ve Etkileri Konusunda Turizm Öğrencilerinin Algılarının Belirlenmesi”, Turizm Akademik Dergisi, 4(2), 2017, s.107-119. 